\title{
Penerapan Metode RAD dalam Perancangan Sistem Informasi Aplikasi Penelusuran Putusan (SIAPP)
}

\author{
Riscy Nuku ${ }^{1}$, Erich J. A. Masihor ${ }^{2}$, Rikson L. Pasaribu ${ }^{3}$ \\ 1 Program Studi Teknik Informatika UNIMA;2 Program Studi Teknik Informatika UNIMA; 3 Program Studi Teknik Informatika UNIMA \\ Email:17210054@unima.ac.id
}

\begin{abstract}
The Tondano 1B District Court is one of the courts located in North Sulawesi Province. In the process of taking a copy of the current ruling, the Tondano District Court is still a manual. A copy of the decision itself is very useful because through a copy of the decision, it can be seen the legal reasoning behind the judge's decision in completing a trial. In addition, a copy of the court's decision is also a prerequisite for the parties when they want to file for legal remedies. Because, the main ingredient in compiling appeal or cassation memory is a copy of the decision at the first level. If a copy of the decision does not reach the parties, there is a chance that the opportunity for justice seekers will be lost to submit legal remedies. Because the process is still manual, it requires quite a long time because the case owner must come directly to the Tondano District Court to ask for the availability of a copy of the decision. Then, it is necessary to design an Information System that can facilitate the case and the Tondano District Court in making copies of decisions at the Tondano District Court. This information system is called Sistem Informasi Aplikasi Penelusuran Perkara (SIAPP) and is designed / developed by the Rapid Application Development (RAD) method. With SIAPP, the case party can see the status of the availability of copies of decisions so that they can submit applications for taking copies of decisions from SIAPP and this will save the case and the Tondano District Court time.
\end{abstract}

Keywords — Rapid Application Development (RAD), Information System.

\begin{abstract}
Abstrak - Pengadilan Negeri Tondano 1B adalah salah satu pengadilan yang berada di Provinsi Sulawesi Utara. Dalam proses pengambilan salinan putusan saat ini, Pengadilan Negeri Tondano masih bersifat manual. Salinan putusan sendiri sangat berguna karena lewat salinan putusan, dapat diketahui legal reasoning dibalik keputusan hakim dalam menyelesaikan sebuah sengeketa. Selain itu, salinan putusan pengadilan juga merupakan prasyarat bagi para pihak ketika hendak mengajukan upaya hukum. Sebab, bahan utama dalam menyusun memori banding atau memori kasasi adalah salinan putusan pada tingkat pertama. Jika salinan putusan tak kunjung sampai ke tangan para pihak, ada peluang hilangnya kesempatan para pencari keadilan untuk mengajukan upaya hukum. Karena proses yang masih manual maka membutuhkan waktu yang cukup lama karena pihak pemilik perkara harus datang langsung ke Pengadilan Negeri Tondano untuk menanyakan ketersediaan salinan putusan. Maka, perlu merancang Sistem Informasi yang dapat mempermudah pihak perkara maupun pihak Pengadilan Negeri Tondano dalam pengambilan salinan putusan di Pengadilan Negeri Tondano. Sisten informasi ini bernama Sistem Informasi Aplikasi Penelusran Putusan (SIAPP) dan dirancang/dikembangkan metode Rapid Application Development (RAD). Dengan SIAPP maka pihak perkara dapat melihat status ketersediaan salinan putusan sehingga mereka bisa mengajukan permohonan pengambilan salinan putusan dari SIAPP dan ini akan menghemat waktu pihak perkara dan pihak Pengadilan Negeri Tondano.
\end{abstract}

Kata Kunci- Rapid Application Development (RAD), Sistem Informasi.

\section{Pendahuluan}

Pengadilan Negeri adalah sebuah lembaga yang berfungsi untuk memeriksa, memutus dan menyelesaikan perkara pidana dan perdata bagi rakyat pencari keadilan pada umumnya. Dalam beberapa tahun terakhir Pengadilan Negeri semakin meningkatkan pelayanan yang berbasis elektronik dan online, salah satunya Pengadilan Negeri Tondano 1B. Pengadilan Negeri Tondano 1B adalah salah satu pengadilan yang berada di Provinsi Sulawesi Utara. Pengadilan Negeri Tondano dibentuk pada Tahun 1967 dengan klasifikasi Pengadilan Kelas IIa, akan tetapi pada waktu itu belum ada gedung sendiri, sehingga untuk perkantoran hanya menyewa rumah rakyat. Bahwa pada Tahun 1972/1973 Pengadilan Negeri Tondano mendapat anggaran Pembangunan Gedung Kantor, dan pembangunannya telah selesai dan diresmikan pada tanggal 10 Pebruari 1973.

Dalam proses pengambilan salinan putusan saat ini, Pengadilan Negeri Tondano masih bersifat manual yang mana membutuhkan waktu yang cukup lama karena pihak pemilik perkara harus datang langsung ke Pengadilan Negeri Tondano untuk menanyakan ketersediaan salinan putusan. Salinan putusan sendiri sangat berguna karena lewat salinan putusan, dapat diketahui legal reasoning dibalik keputusan hakim dalam menyelesaikan sebuah sengeketa. Selain itu, salinan putusan pengadilan juga merupakan prasyarat bagi para pihak ketika hendak mengajukan upaya hukum. Sebab, bahan utama dalam menyusun memori banding atau memori kasasi adalah salinan putusan pada tingkat pertama. Jika salinan putusan tak kunjung sampai ke tangan para pihak, ada peluang hilangnya kesempatan para pencari keadilan untuk mengajukan upaya hukum.

Dibutuhkan sebuah sistem informasi untuk Pengadilan Negeri Tondano sebagai solusi untuk masalah pengambilan salinan putusan. Sistem informasi ini berbentuk website dan 
dapat diakses disemua sistem operasi selama ada browser dan koneksi internet. Dengan sistem informasi ini diharapkan dapat memberikan informasi mengenai ketersidaan salinan putusan sehingga pihak perkara dapat mengajukan permohonan untuk pengambilan salinan putusan secara online. Sehingga mengoptimalkan waktu dari pihak perkara dan juga mengoptimalkan waktu dari pihak Pengadilan Negeri Tondano dalam menyediakan salinan putusan.

\section{LANDASAN TEORI}

\section{A. Sistem Informasi}

Menurut Laudon (2012:16) sistem informasi adalah komponen-komponen yang saling berkaitan yang bekerja bersama-sama untuk mengumpulkan, mengolah, menyimpan, dan menampilkan informasi untuk mendukung pengambilan keputusan, koordinasi, pengaturan, analisa, dan visualisasi pada sebuah organisasi. Menurut Whitten, Bentley, dan Ditman (2009:10) sistem informasi adalah pengaturan orang, data, proses, dan informasi (TI) atau teknologi informasi yang berinteraksi untuk mengumpulkan, memproses, menyimpan dan menyediakan sebagai output informasi yang diperlukan untuk mendukung sebuah intansi atau organisasi. Bedasarkan dari pernyataan di atas, maka dapat disimpulkan bahwa Sistem informasi merupakan suatu sistem yang mempunyai kemampuan untuk mengumpulkan informasi dari semua sumber dan menggunakan berbagai media untuk menampilkan informasi.

\section{B. Website}

Menurut (Agus Hariyanto, 2015), Website adalah: "Web dapat diartikan sebagai kumpulan halaman yang menampilkan informasi data teks, data gambar, data animasi, suara, video dan gabungan dari semuanya, baik yang bersifat statis maupun dinamis yang membentuk satu rangkaian bangunan yang saling terkait, dimana masingmasing dihubungkan dengan jaringan-jaringan halaman (hyperlink)".

Menurut Rohi Abdulloh (2015) web adalah: "Sekumpulan halaman yang terdiri dari beberapa halaman yang berisi informasi dalam bentuk data digital baik berupa text, gambar, video, audio, dan animasi lainnya yang disediakan melalui jalur koneksi internet". Berdasarkan uraian, penulis menyimpulkan bahwa web adalah Sebuah software yang berfungsi untuk menampilkan dokumen - dokumen pada suatu web yang membuat pengguna dapat mengakses internet melalui software yang terkoneksi dengan internet.

\section{Rapid Application Development}

Rapid Application Development (RAD) adalah model proses pengembangan perangkat lunak yang bersifat inkremental terutama untuk waktu pengerjaan yang pendek. Model RAD adalah adptasi dari model waterfall versi kecepatan tinggi dengan menggunakan waterfall untuk pengembangan setiap komponen perangkat lunak.

Menurut Kendall (2010), RAD adalah suatu pendekatan berorientasi objek terhadap pengembangan sistem yang mencakup suatu metode pengembangan serta perangkat-perangkat lunak. RAD bertujuan mempersingkat waktu yang biasanya diperlukan dalam siklus hidup pengembangan sistem tradisional antara perancangan dan penerapan suatu sistem informasi. Pada akhirnya, RAD sama-sama berusaha memenuhi syaratsyarat bisnis yang berubah secara cepat.

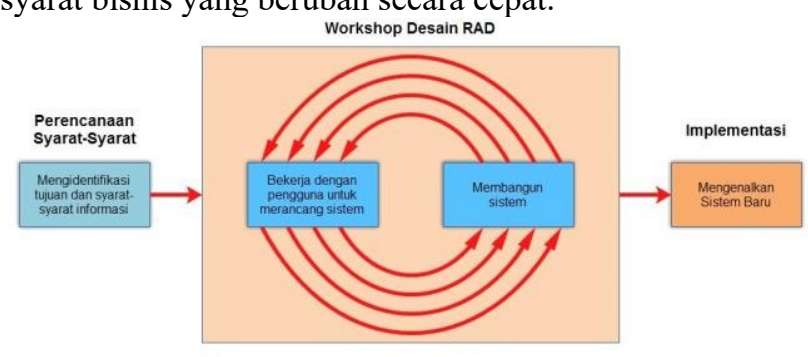

Gbr. 1 Model RAD

Menurut Kendall (2010), terdapat tiga fase dalam RAD yang melibatkan penganalisis dan pengguna dalam tahap penilaian, perancangan, dan penerapan. Adapun ketiga fase tersebut adalah requirements planning (perencanaan syaratsyarat), RAD design workshop (workshop desain RAD), dan implementation (implementasi). Sesuai dengan metodologi RAD menurut Kendall (2010), berikut ini adalah tahaptahap pengembangan aplikasi dari tiap-tiap fase pengembangan aplikasi.

1) Requirements Planning (Perencanaan SyaratSyarat)

Dalam fase ini, pengguna dan penganalisis bertemu untuk mengidentifikasikan tujuan-tujuan aplikasi atau sistem serta untuk megidentifikasikan syarat-syarat informasi yang ditimbulkan dari tujuan-tujuan tersebut. Orientasi dalam fase ini adalah menyelesaikan masalahmasalah perusahaan. Meskipun teknologi informasi dan sistem bisa mengarahkan sebagian dari sistem yang diajukan, fokusnya akan selalu tetap pada upaya pencapaian tujuan-tujuan perusahaan (Kendall, 2010).

\section{2) RAD Design Workshop (Workshop Desain RAD)}

Fase ini adalah fase untuk merancang dan memperbaiki yang bisa digambarkan sebagai workshop. Penganalisis dan dan pemrogram dapat bekerja membangun dan menunjukkan representasi visual desain dan pola kerja kepada pengguna. Workshop desain ini dapat dilakukan selama beberapa hari tergantung dari ukuran aplikasi yang akan dikembangkan. Selama workshop desain RAD, pengguna merespon prototipe yang ada dan penganalisis memperbaiki modul-modul yang dirancang berdasarkan respon pengguna. Apabila sorang pengembangnya merupakan pengembang atau pengguna yang berpengalaman, Kendall menilai bahwa usaha kreatif ini dapat mendorong pengembangan sampai pada tingkat terakselerasi (Kendall, 2010). 


\section{3) Implementation (Implementasi)}

Pada fase implementasi ini, penganalisis bekerja dengan para pengguna secara intens selama workshop dan merancang aspek-aspek bisnis dan nonteknis perusahaan. Segera setelah aspek-aspek ini disetujui dan sistem-sistem dibangun dan disaring, sistem-sistem baru atau bagian dari sistem diujicoba dan kemudian diperkenalkan kepada organisasi (Kendall, 2010).

\section{LANGKAH PEMECAHAN MASAlAH}

A. Tahapan Metode Pengembangan Sistem

a. Requirements Planning (Perencanaan SyaratSyarat)

b. RAD Design Workshop (Workshop Desain RAD)

- Pemodelan Proses Bisnis

- Pemodelan Database

- Pemodelan UML

c. Implementation (Implementasi) dan Pengujian

\section{B. Tools Pemodelan}

Dalam perancangan SIAPP kami menggunakan UML (Unified Modeling Language) sebagai pemodelan yang merupakan sebuah standarisasi bahasa pemodelan untuk pembangunan atau perancangan perangkat lunak yang dibangun dengan menggunakan teknik pemrograman berorientasi objek. Untuk pemodelan ini kami menggunakan tools seperti Microsoft Visio.

\section{Metode Pengumpulan Data}

Pada tahap pengumpulan data, kami konsultasi dengan Kasub Kepegawaian dan Ibu Sekretaris mengenai kebutuhan-kebutuhan sistem. Data yang kami peroleh dari hasil konsultasi ini menjadi patokan dalam pembuatan atau perancangan Sistem Informasi Aplikasi Penelusuran Putusan (SIAPP).

\section{HASIL DAN PEMBAHASAN}

Dalam pengembangan SIAPP kami menggunakan model Rapid Application Development (RAD) sebagai metode pengembangan sistem yang pendekatannya berorientasi objek yang memiliki beberapa tahapan. Berikut adalah proses pembuatan SIAPP berdasarkan tahapan-tahapan yang ada di model RAD:

\section{A. Requirements Planning}

1) System Requirements

Dari hasil konsultasi kami, berikut ini adalah spesifikasi kebutuhan (system requirement) dari Sistem Informasi Aplikasi Penelusuran Perkara (SIAPP):

TABEL I. SYSTEM REQUIREMENTS

\begin{tabular}{|c|c|c|}
\hline $\begin{array}{c}\text { Halaman } \\
\text { Login }\end{array}$ & Halaman Admin & $\begin{array}{c}\text { Halaman } \\
\text { Masyarak (Pihak } \\
\text { Perkara) }\end{array}$ \\
\hline
\end{tabular}

\begin{tabular}{|c|c|c|}
\hline $\begin{array}{l}\text { Halaman } \\
\text { login } \\
\text { khusus } \\
\text { untuk admin } \\
\text { agar tidak } \\
\text { semua } \\
\text { orang dapat } \\
\text { mengakses } \\
\text { data di } \\
\text { SIAPP }\end{array}$ & 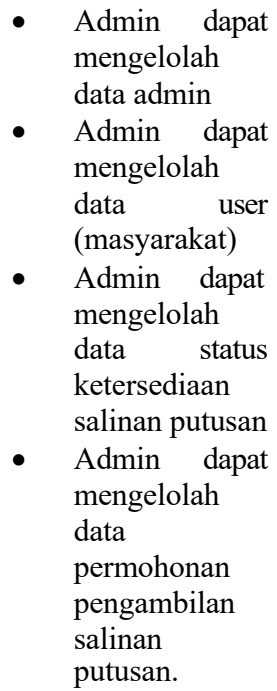 & \begin{tabular}{|l} 
- \\
User \\
(masyarakat) \\
dapat melihat \\
status \\
ketersediaan \\
salinan putusan \\
User \\
(masyarakat) \\
dapat mengisi \\
dan mengirim \\
formulir \\
permohonan \\
pengambilan \\
salinan putusan
\end{tabular} \\
\hline
\end{tabular}

2) Resource Requirements

TABEL III. RESOURCE REQUIREMENTS

\begin{tabular}{|l|ll|}
\hline Sistem Operasi & \multicolumn{2}{l|}{ Windows !0 64 bit } \\
\hline Tools \& Software & $\bullet$ & Sublime Text 3 \\
& $\bullet$ & XAMPP \\
& $\bullet$ & Adobe Photoshop CS6 \\
& $\bullet$ & Mozilla Firefox \\
& $\bullet$ & Microsoft Visio \\
& $\bullet$ & Bizagi Modeler \\
Sumber Daya & $\bullet$ & Riscy Nuku \\
Manusis & $\bullet$ & Rikson L. Pasaribu \\
& $\bullet$ & Erich J. A. Masihor \\
& $\bullet$ & Dosen Pembimbing \\
& & Kerja Praktek \\
& $\bullet$ & Pembimbing Lapangan \\
& & \\
\hline
\end{tabular}

B. RAD Design Workshop

1) Pemodelan $U M L$

Dalam pemodelan sistem ini kami menggunakan UML (Unified Modeling Language). UML yang digunakan yaitu Class Diagram, Use Case Diagram, Activity Diagram, dan Sequence Diagram.

a) Class Diagram

Berikut adalah Penggambaran setiap kelas yang ada pada sistem SIAPP serta hubungan-hubungan antar kelas tersebut. 


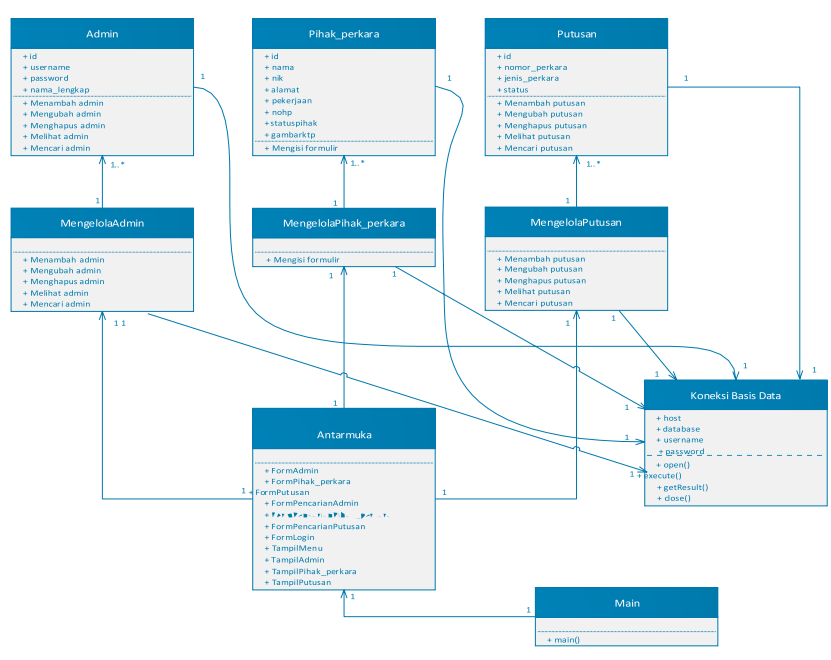

Gbr. 2 Class Diagram SIAPP

Berikut adalah penjelasam dari Class Diagram SIAPP Pengadilan Negeri Tondano.

TABEL IIIII. CLASS DIAGRAM SIAPP

\begin{tabular}{|c|c|c|}
\hline No & Nama Kelas & Keterangan \\
\hline 1 & Main & Merupakan kelas main \\
\hline 2 & Antarmuka & $\begin{array}{l}\text { Merupakan kelas yang menangani } \\
\text { tampilan. }\end{array}$ \\
\hline 3 & MengelolaAdmin & $\begin{array}{l}\text { Merupakan kelas proses yang } \\
\text { diambil dari pendefinisian use } \\
\text { case mengelola data admin yang } \\
\text { didalamnya harus juga menangani } \\
\text { proses menambah admin, } \\
\text { mengubah data admin, dan } \\
\text { menghapus data admin. }\end{array}$ \\
\hline 4 & MengelolaPihak_perkara & $\begin{array}{l}\text { Merupakan kelas proses yang } \\
\text { diambil dari pendefinisian use } \\
\text { case menghapus daftar } \\
\text { permohonan. }\end{array}$ \\
\hline 5 & MengelolaPutusan & $\begin{array}{l}\text { Merupakan kelas proses yang } \\
\text { diambil dari pendefinisian use } \\
\text { case mengelola data perkara yang } \\
\text { didalamnya harus juga menangani } \\
\text { proses menambah perkara, } \\
\text { mengubah data perkara, dan } \\
\text { menghapus data perkara. }\end{array}$ \\
\hline 6 & Admin & $\begin{array}{l}\text { Merupakan kelas data yang } \\
\text { digunakan untuk memproses } \\
\text { segala pengaksesan terhadap tabel } \\
\text { admin. }\end{array}$ \\
\hline 7 & Pihak_perkara & $\begin{array}{l}\text { Merupakan kelas data yang } \\
\text { digunakan untuk memproses } \\
\text { pengaksesan terhadap tabel pihak } \\
\text { perkara. }\end{array}$ \\
\hline 8 & Putusan & $\begin{array}{l}\text { Merupakan kelas data yang } \\
\text { digunakan untuk memproses } \\
\text { segala pengaksesan terhadap tabel } \\
\text { Putusan }\end{array}$ \\
\hline 9 & Koneksi Basis Data & $\begin{array}{l}\text { Merupakan kelas utilitas untuk } \\
\text { koneksi ke basis data dan } \\
\text { melakukan query. }\end{array}$ \\
\hline
\end{tabular}

\section{b) Use Case Diagram}

Pada Use Case SIAPP terdapat 2 aktor yaitu pertama Admin yang ditunjuk oleh pihak PN dan banyak use case yaitu Login, Logout, Perkara, Pemohon, Admin, Tambah Data, Ubah Data, Hapus Data dan Simpan. Lalu aktor Pihak Perkara yang ingin mengambil Salinan putusan perkara dan banyak use case yaitu Cek Perkara dan Mengisi Formulir.

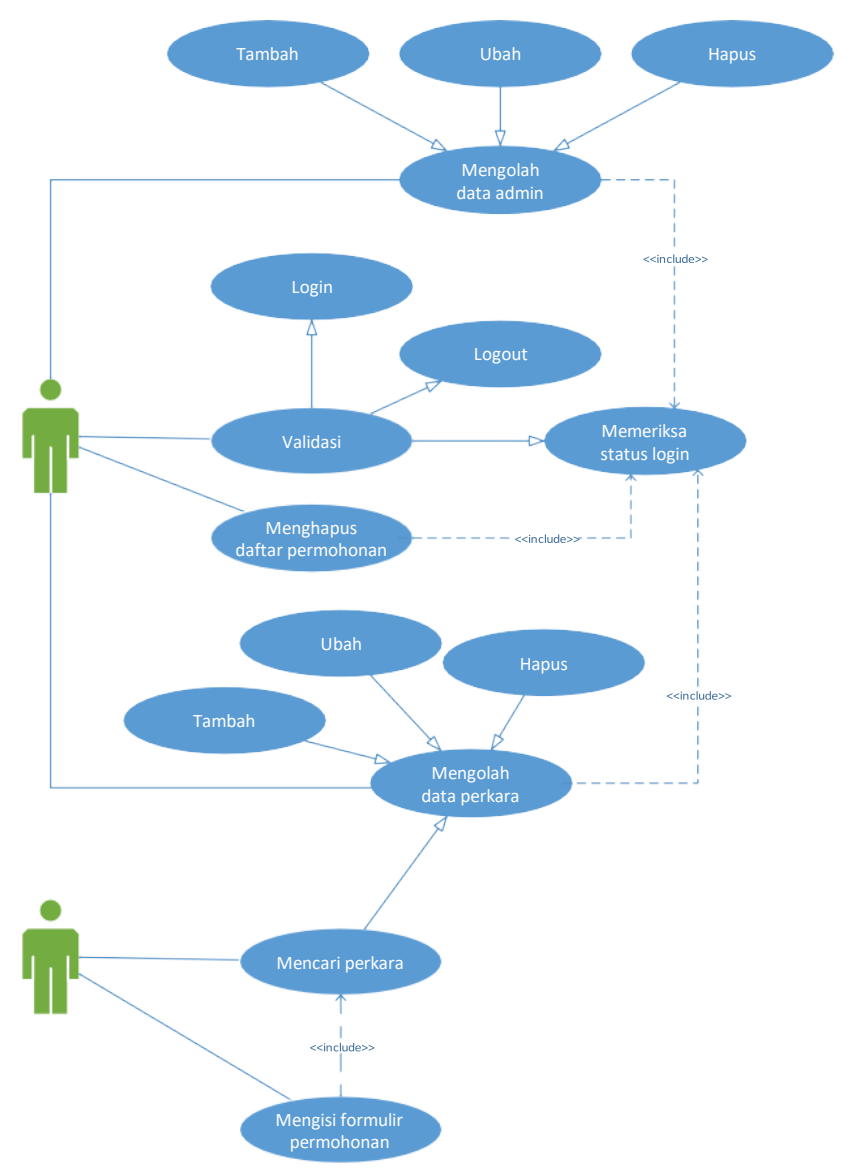

Gbr. 4 Use Case Diagram SIAPP

\section{* Use Case Skenario}

- Definisi Aktor

Berikut adalah deskripsi pendefinisian actor pada Website SIAPP Pengadilan Negeri Tondano:

TABEL IVV. TABEL DEFINISI AKTOR

\begin{tabular}{|l|l|l|}
\hline No & \multicolumn{1}{|c|}{ Aktor } & \multicolumn{1}{c|}{ Deskripsi } \\
\hline 1 & Admin & $\begin{array}{l}\text { Merupakan pengguna yang memiliki } \\
\text { hak akses untuk melakukan seluruh } \\
\text { kewenangan / tugas yang ada pada } \\
\text { system. }\end{array}$ \\
\hline 2 & $\begin{array}{l}\text { Masyrakat } \\
\text { (Pihak } \\
\text { Perkara) }\end{array}$ & $\begin{array}{l}\text { Merupakan pengguna yang hanya } \\
\text { dapat melihat informasi ketersidiaan } \\
\text { salinan putusan dan mengajukan } \\
\text { permohonan pengambilam salinan } \\
\text { putusan. }\end{array}$ \\
\hline
\end{tabular}

- Defenisi Use Case

Berikut adalah deskripsi pendefinisian use case SIAPP Pengadilan Negeri Tondano:

TABEL V. TABel Definisi USE CASE

\begin{tabular}{|l|l|l|}
\hline No & \multicolumn{1}{|c|}{ Use Case } & \multicolumn{1}{|c|}{ Deskripsi } \\
\hline 1 & Validasi & $\begin{array}{l}\text { Merupakan proses pengecekan } \\
\text { hak akses siapa yang berhak }\end{array}$ \\
& & $\begin{array}{l}\text { mengakses proses pengolahandata } \\
\end{array}$ \\
& & SIAPP yang dalam sistem ini \\
& & adalah admin. \\
\hline
\end{tabular}




\begin{tabular}{|c|c|c|}
\hline & & $\begin{array}{ll}\text { Merupakan generalisasi } & \text { dari } \\
\text { proses login, logout, } & \text { dan } \\
\text { memeriksa status login. } & \end{array}$ \\
\hline 2 & Login & $\begin{array}{l}\text { Merupakan proses yang hanya } \\
\text { dilakukan oleh admin yang } \\
\text { memiliki hak akses untuk } \\
\text { melakukan seluruh kewenangan / } \\
\text { tugas yang ada pada system. }\end{array}$ \\
\hline 3 & Logout & $\begin{array}{l}\text { Merupakan proses untuk } \\
\text { melakukan logout admin SIAPP }\end{array}$ \\
\hline 4 & $\begin{array}{l}\text { Memeriksa status } \\
\text { login }\end{array}$ & $\begin{array}{l}\text { Merupakan proses untuk } \\
\text { memeriksa apakah pengguna } \\
\text { sistem informasi sudah melakukan } \\
\text { login atau belum. }\end{array}$ \\
\hline 5 & $\begin{array}{l}\text { Mengelola } \\
\text { admin }\end{array}$ & $\begin{array}{l}\text { Mengelola data admin merupakan } \\
\text { proses generalisasi yang yang } \\
\text { meliputi } 3 \text { buah proses } \\
\text { pengelolaan data admin yaitu, } \\
\text { menambah admin, mengubah data } \\
\text { admin, dan menghapus data } \\
\text { admin. }\end{array}$ \\
\hline 6 & $\begin{array}{l}\text { Menambah data } \\
\text { admin }\end{array}$ & $\begin{array}{l}\text { akan proses yang dilakukan } \\
\text { dmin untuk menambah }\end{array}$ \\
\hline 7 & $\begin{array}{l}\text { Mengubah } \\
\text { admin }\end{array}$ & $\begin{array}{l}\text { Merupakan proses yang dilakukan } \\
\text { oleh admin untuk mengubah data } \\
\text { admin. }\end{array}$ \\
\hline 8 & hapus data & $\begin{array}{l}\text { Merupakan proses yang dilakukan } \\
\text { oleh admin untuk menghapus data } \\
\text { admin }\end{array}$ \\
\hline 9 & perkara & $\begin{array}{l}\text { Mengelola data perkara } \\
\text { merupakan proses generalisasi } \\
\text { yang yang meliputi } 3 \text { buah proses } \\
\text { pengelolaan data perkara yaitu, } \\
\text { menambah data perkara, } \\
\text { mengubah data perkara, dan } \\
\text { menghapus data perkara. }\end{array}$ \\
\hline 10 & $\begin{array}{l}\text { Menambah data } \\
\text { perkara }\end{array}$ & $\begin{array}{l}\text { Merupakan proses yang dilakukan } \\
\text { oleh admin untuk menambah data } \\
\text { perkara }\end{array}$ \\
\hline 11 & $\begin{array}{l}\text { Mengubah } \\
\text { perkara }\end{array}$ & $\begin{array}{l}\text { Merupakan proses yang dilakukan } \\
\text { oleh admin untuk mengubah data } \\
\text { perkara }\end{array}$ \\
\hline 12 & $\begin{array}{l}\text { Menghapus data } \\
\text { perkara }\end{array}$ & $\begin{array}{l}\text { Merupakan proses yang dilakukan } \\
\text { oleh admin untuk menghapus data } \\
\text { perkara }\end{array}$ \\
\hline 13 & $\begin{array}{l}\text { Mencari/mengecek } \\
\text { data perkara }\end{array}$ & $\begin{array}{l}\text { Merupakan proses yang dilakukan } \\
\text { oleh pihak perkara untuk melihat } \\
\text { ststus ketersediaan salinan } \\
\text { putusan. }\end{array}$ \\
\hline 14 & $\begin{array}{l}\text { formulir } \\
\text { nan }\end{array}$ & $\begin{array}{l}\text { Merupakan proses yang dilakukan } \\
\text { oleh pihak perkara untuk mengisi } \\
\text { form permohonan pengambilan } \\
\text { salinan putusan }\end{array}$ \\
\hline 15 & $\begin{array}{l}\text { is daftar } \\
\text { an }\end{array}$ & $\begin{array}{l}\text { Merupakan proses yang dilakukan } \\
\text { oleh admin untuk menghapus data } \\
\text { daftar permohonan }\end{array}$ \\
\hline
\end{tabular}

c) Activity Diagram

- Activity Diagram Admin SIAPP

Activity Diagram Admin SIAPP menggambarkan proses saat Admin akan akan mengakses SIAPP. Setelah membuka halaman Admin SIAPP, admin otomatis masuk di halaman Beranda yang mana halaman beranda memuat daftar permohonan pengambilan salinan putusan. Didalam halaman admin terdapat menu input data perkara, data admin. Di menu input data perkara admin bisa tambah data, ubah data, dan hapus data. Begitu pula di menu data admin, admin bisa tambah data, ubah data, dan hapus data. Terakhir di beranda admin dapat menghapus data daftar permohonan pengambilan Salinan putusan.

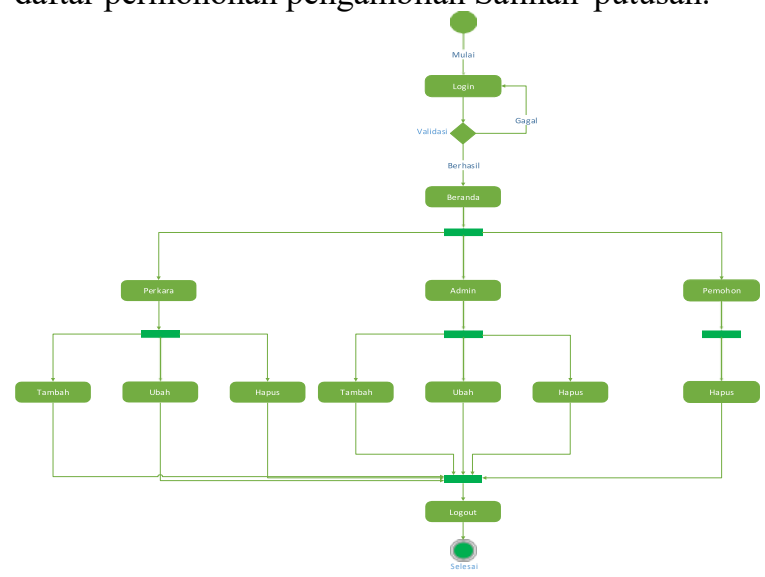

Gbr. 5 Activity Diagram SIAPP

- Activity Diagram Pihak Perkara

Activity diagram Pihak Perkara menggambarkan proses saat pihak perkara akan mengakses SIAPP yang didalamnya tersedia informasi mengenai ketersediaan putusan perkara. Disini ada menu beranda untuk melihat penjelesan dari semua menu yang ada di SIAPP. Menu tata cara berfungsi untuk melihat langkah-langkah proses pengisian form permohonan. Dalam menu surat putusan pihak perkara dapat melihat informasi ketersediaan surat putusan perkara dan mengisi form permohonan pengambilan salinan putusan. Terakhir ada menu tentang siapp.

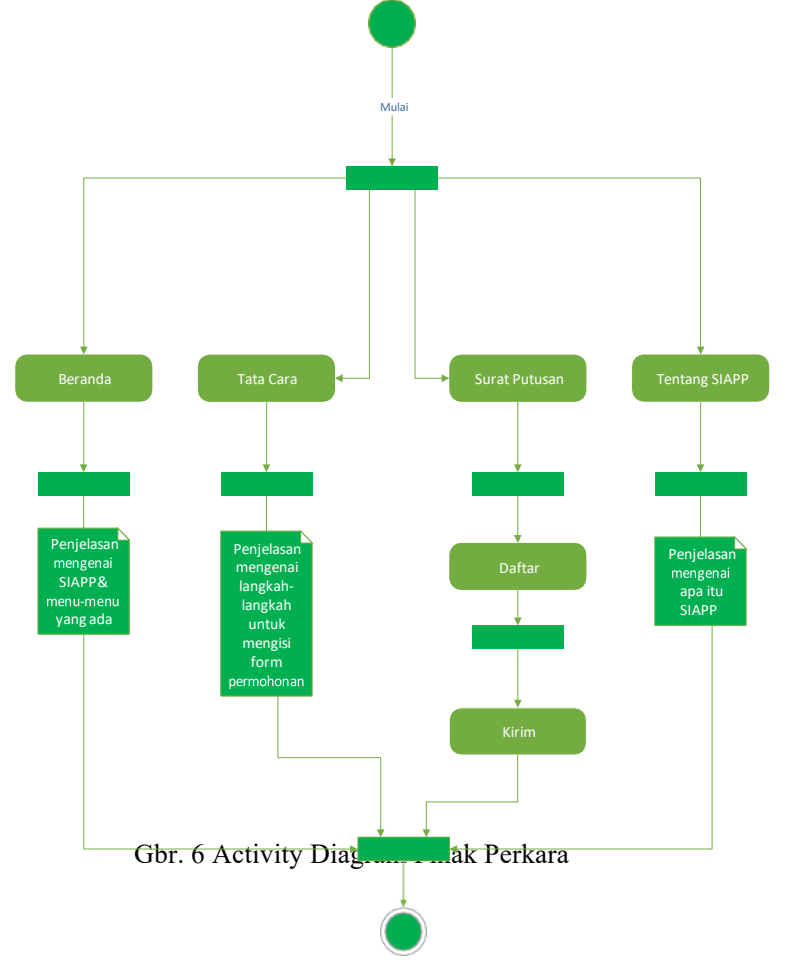




\section{d) Sequence Diagram}

Sequence diagram menggambarkan interaksi antar objek di dalam dan di sekitar sistem (termasuk pengguna, display/form) berupa message yang digambarkan terhadap waktu.

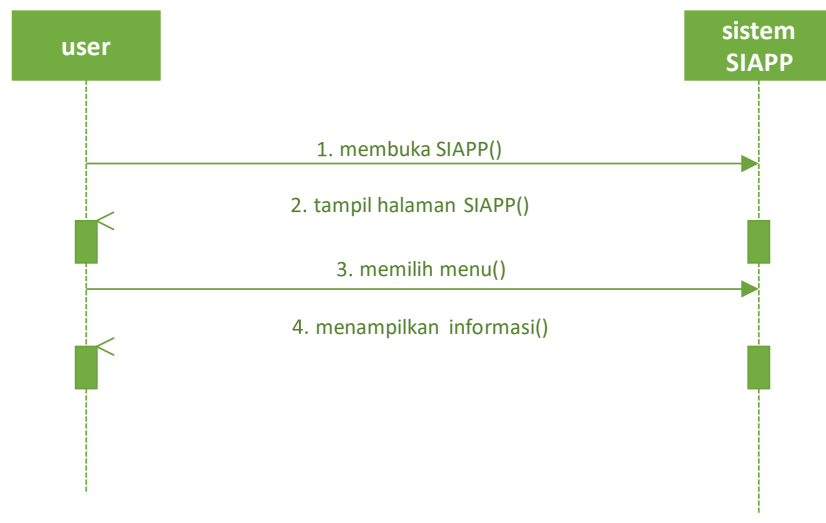

Gbr. 7 Sequence Diagram membuka dan menutup system

\section{Pembuatan Kode Program}

Tahap pembuatan kode program adalah menulis kode program sesuai dengan hasil yang diperoleh dari tahap analisis kebutuhan perangkat lunak dan pemodelan yang dilakukan pada tahap design. Dalam pembuatan kode program Sistem Informasi Aplikasi Penelusuran Putusan (SIAPP) kami menggunakan Template Boostrap, MySQL sebagai DBMS (Database Management Sistem) dan Sublime Text 3 sebagai text editor.

\section{Implemantation and Testing}

1. Impelementasi

Pada implementasi sistem beberapa hal yang dilakukan antara lain, menulis pengetahuan yang sudah direpresentasikan dengan bahasa pemrograman.

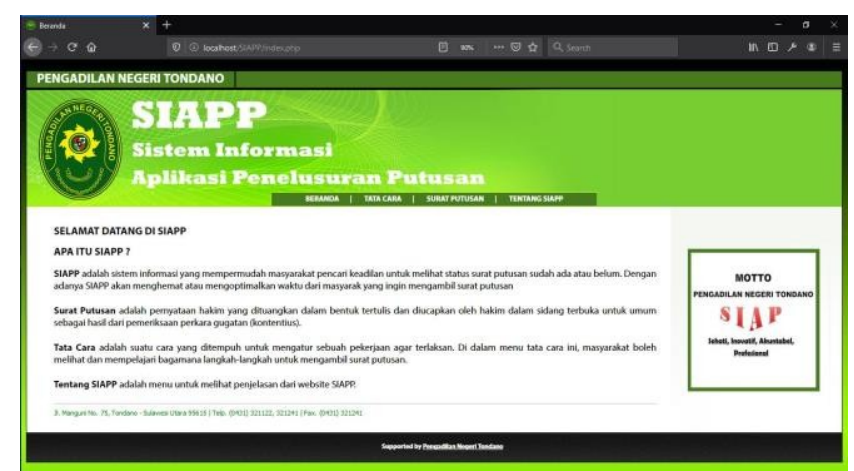

Gbr. 7 halaman beranda pihak perkara

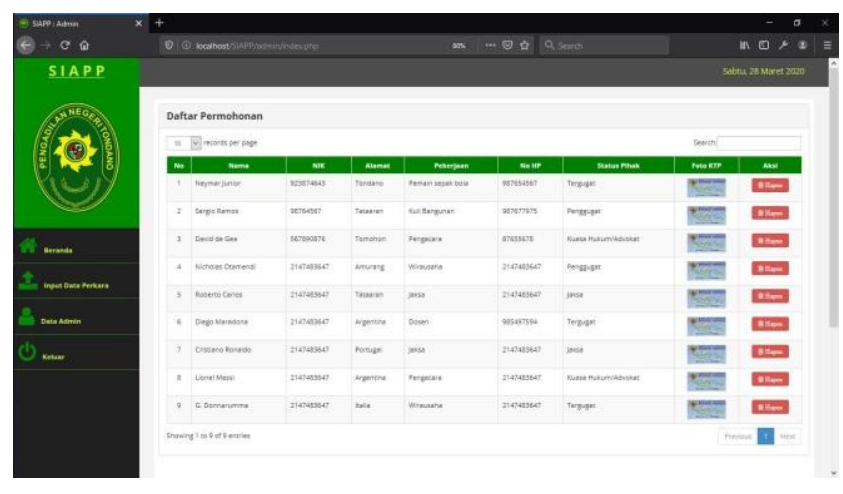

Gbr. 8 halaman beranda admin

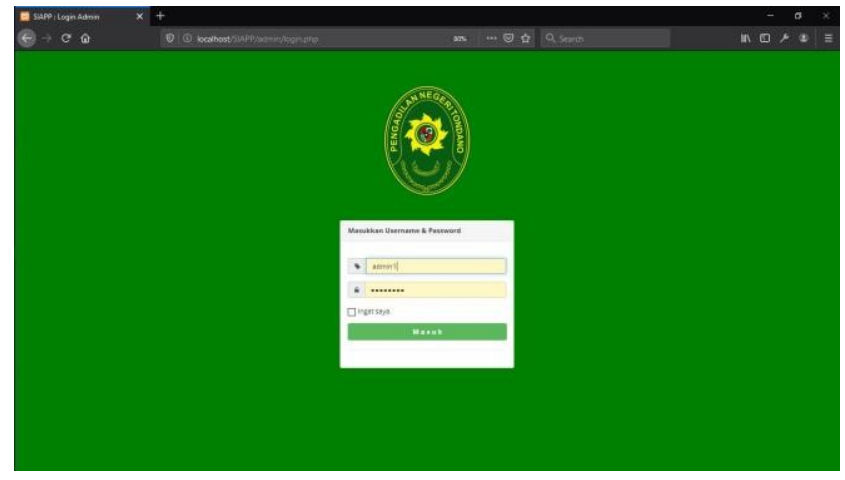

2. Testing

Gbr. 9 halaman login admin

Pada tahapan pengujian kami menggunakan metode kotak hitam (blackbox testing) pada pengujian Sistem Informasi Aplikasi Penelusuran Putusan. Blackbox testing adalah pengujian yang dilakukan untuk mengamati dan mengevaluasi hanya penampilan eksternal (antarmuka), tanpa mengetahui apa yang sebenarnya terjadi dalam codingan. Dalam tahapan ini kami memaparkan dan melakukan pengetesan sistem pada kasub kepegawaian, sekretaris dan beberapa pegawai lainnya yang hasilnya pada tabel dibawah.

\begin{tabular}{|c|l|l|l|l|}
\hline $\begin{array}{l}\mathrm{N} \\
\mathrm{o}\end{array}$ & $\begin{array}{l}\text { Tujuan yang } \\
\text { ingin } \\
\text { dicapai }\end{array}$ & \multicolumn{1}{|c|}{ Input } & Output & Hasil \\
\hline 1 & $\begin{array}{l}\text { Menampilka } \\
\text { n halaman } \\
\text { login }\end{array}$ & $\begin{array}{l}\text { Menjalanka } \\
\text { n aplikasi }\end{array}$ & $\begin{array}{l}\text { SIAPP } \\
\text { menampilka } \\
\text { n halaman } \\
\text { login }\end{array}$ & $\begin{array}{l}\text { Tercapa } \\
\mathrm{i}\end{array}$ \\
\hline 2 & $\begin{array}{l}\text { Melakukan } \\
\text { login }\end{array}$ & $\begin{array}{l}\text { Memasukan } \\
\text { username } \\
\text { dan } \\
\text { password }\end{array}$ & $\begin{array}{l}\text { admin dapat } \\
\text { masuk } \\
\text { kedalam } \\
\text { halaman } \\
\text { admin } \\
\text { SIAPP }\end{array}$ & $\begin{array}{l}\text { Tercapa } \\
\mathrm{i}\end{array}$ \\
\hline 3 & $\begin{array}{l}\text { Menampilka } \\
\mathrm{n} \text { halaman } \\
\text { daftar } \\
\text { permohonan } \\
\text { pengambila } \\
\mathrm{n} \text { salinan } \\
\text { putusan }\end{array}$ & $\begin{array}{l}\text { Menekan } \\
\text { tombol } \\
\text { Beranda } \\
\text { pada } \\
\text { halaman } \\
\text { admin }\end{array}$ & $\begin{array}{l}\text { SIAPP } \\
\text { menampilka } \\
\text { n halaman } \\
\text { daftar } \\
\text { permohonan } \\
\text { pengambila } \\
\text { n salinan } \\
\text { putusan }\end{array}$ & i \\
\hline
\end{tabular}




\begin{tabular}{|c|c|c|c|c|}
\hline 4 & $\begin{array}{l}\text { Menghapus } \\
\text { data daftar } \\
\text { permohonan } \\
\text { pengambila } \\
\text { n salinan } \\
\text { putusan }\end{array}$ & $\begin{array}{l}\text { Menekan } \\
\text { tombol } \\
\text { hapus data }\end{array}$ & $\begin{array}{l}\text { Data } \\
\text { dihapus dari } \\
\text { basis data }\end{array}$ & $\begin{array}{l}\text { Tercapa } \\
\mathrm{i}\end{array}$ \\
\hline 5 & $\begin{array}{l}\text { Menambah } \\
\text { data perkara }\end{array}$ & $\begin{array}{l}\text { Memasukan } \\
\text { data perkara } \\
\text { kedalam } \\
\text { form yang } \\
\text { disediakan }\end{array}$ & $\begin{array}{l}\text { Data buku } \\
\text { ditambah } \\
\text { kedalam } \\
\text { basis data }\end{array}$ & $\begin{array}{l}\text { Tercapa } \\
\mathrm{i}\end{array}$ \\
\hline 6 & $\begin{array}{l}\text { Mengubah } \\
\text { data perkara }\end{array}$ & $\begin{array}{l}\text { Memasukan } \\
\text { data perkara } \\
\text { yang baru }\end{array}$ & $\begin{array}{l}\text { Data perkara } \\
\text { diubah }\end{array}$ & $\begin{array}{l}\text { Tercapa } \\
\mathrm{i}\end{array}$ \\
\hline 7 & $\begin{array}{l}\text { Menghapus } \\
\text { data perkara }\end{array}$ & $\begin{array}{l}\text { Menekan } \\
\text { tombol } \\
\text { hapus data }\end{array}$ & $\begin{array}{l}\text { Data } \\
\text { dihapus dari } \\
\text { basis data }\end{array}$ & $\begin{array}{l}\text { Tercapa } \\
\mathrm{i}\end{array}$ \\
\hline 8 & $\begin{array}{l}\text { Menampilka } \\
\mathrm{n} \text { halaman } \\
\text { data admin }\end{array}$ & $\begin{array}{l}\text { Menekan } \\
\text { tombol data } \\
\text { admin }\end{array}$ & $\begin{array}{l}\text { SIAPP } \\
\text { menampilka } \\
\mathrm{n} \text { halaman } \\
\text { data admin }\end{array}$ & $\begin{array}{l}\text { Tercapa } \\
\mathrm{i}\end{array}$ \\
\hline 9 & $\begin{array}{l}\text { Menambah } \\
\text { data admin }\end{array}$ & $\begin{array}{l}\text { Memasukan } \\
\text { data } \\
\text { kedalam } \\
\text { form yang } \\
\text { disediakan }\end{array}$ & $\begin{array}{l}\text { Data admin } \\
\text { ditambah } \\
\text { kedalam } \\
\text { basis data }\end{array}$ & $\begin{array}{l}\text { Tercapa } \\
\mathrm{i}\end{array}$ \\
\hline 10 & $\begin{array}{l}\text { Mengubah } \\
\text { data admin }\end{array}$ & $\begin{array}{l}\text { Memasukan } \\
\text { data admin } \\
\text { yang baru }\end{array}$ & $\begin{array}{l}\text { Data admin } \\
\text { diubah }\end{array}$ & $\begin{array}{l}\text { Tercapa } \\
\mathrm{i}\end{array}$ \\
\hline 11 & $\begin{array}{l}\text { Menghapus } \\
\text { data admin }\end{array}$ & $\begin{array}{l}\text { Menekan } \\
\text { tombol } \\
\text { hapus data }\end{array}$ & $\begin{array}{l}\text { Data } \\
\text { dihapus dari } \\
\text { basis data }\end{array}$ & $\begin{array}{l}\text { Tercapa } \\
\mathrm{i}\end{array}$ \\
\hline 12 & $\begin{array}{l}\text { Melakukan } \\
\text { logout }\end{array}$ & $\begin{array}{l}\text { Menekan } \\
\text { tombol } \\
\text { keluar }\end{array}$ & $\begin{array}{l}\text { Admin } \\
\text { keluar dari } \\
\text { halaman } \\
\text { admin } \\
\text { SIAPP }\end{array}$ & $\begin{array}{l}\text { Tercapa } \\
\mathrm{i}\end{array}$ \\
\hline 13 & $\begin{array}{l}\text { Menampilka } \\
\mathrm{n} \text { halaman } \\
\text { beranda } \\
\text { SIAPP } \\
\text { untuk } \\
\text { masyarakat }\end{array}$ & $\begin{array}{l}\text { Menekan } \\
\text { tombol } \\
\text { beranda }\end{array}$ & $\begin{array}{l}\text { SIAPP } \\
\text { menampilka } \\
\mathrm{n} \text { halaman } \\
\text { beranda } \\
\text { untuk } \\
\text { masyarakat }\end{array}$ & $\begin{array}{l}\text { Tercapa } \\
\mathrm{i}\end{array}$ \\
\hline 14 & $\begin{array}{l}\text { Menampilka } \\
\mathrm{n} \text { halaman } \\
\text { tatacara }\end{array}$ & $\begin{array}{l}\text { Menekan } \\
\text { tombol tata } \\
\text { cara }\end{array}$ & $\begin{array}{l}\text { SIAPP } \\
\text { menampilka } \\
\mathrm{n} \text { halaman } \\
\text { tata cara } \\
\text { untuk } \\
\text { masyarakat }\end{array}$ & $\begin{array}{l}\text { Tercapa } \\
\mathrm{i}\end{array}$ \\
\hline 15 & $\begin{array}{l}\text { Menampilka } \\
\mathrm{n} \text { informasi } \\
\text { putusan }\end{array}$ & $\begin{array}{l}\text { Menekan } \\
\text { tombol surat } \\
\text { putusan }\end{array}$ & $\begin{array}{l}\text { Menampilka } \\
\mathrm{n} \text { halaman } \\
\text { surat } \\
\text { putusan } \\
\text { untuk } \\
\text { masyarakat } \\
\end{array}$ & $\begin{array}{l}\text { Tercapa } \\
\mathrm{i}\end{array}$ \\
\hline 16 & $\begin{array}{l}\text { Mencari } \\
\text { informasi } \\
\text { perkara }\end{array}$ & $\begin{array}{l}\text { Memasukka } \\
\mathrm{n} \text { kata kunci } \\
\text { pada form } \\
\text { pencarian }\end{array}$ & $\begin{array}{l}\text { Menampilka } \\
\mathrm{n} \text { informasi } \\
\text { perkara } \\
\text { yang dicari }\end{array}$ & $\begin{array}{l}\text { Tercapa } \\
\mathrm{i}\end{array}$ \\
\hline 17 & $\begin{array}{lr} & \text { Menampilka } \\
\mathrm{n} & \text { form } \\
\end{array}$ & $\begin{array}{l}\text { Menekan } \\
\text { tombol }\end{array}$ & $\begin{array}{lr} & \text { Menampilka } \\
\mathrm{n} & \text { form }\end{array}$ & $\begin{array}{l}\text { Tercapa } \\
\mathrm{i}\end{array}$ \\
\hline
\end{tabular}

\begin{tabular}{|c|c|c|c|c|}
\hline & $\begin{array}{l}\text { permohonan } \\
\text { pengambila } \\
\mathrm{n} \text { salinan } \\
\text { putusan }\end{array}$ & $\begin{array}{l}\text { daftar pada } \\
\text { halaman } \\
\text { surat } \\
\text { putusan }\end{array}$ & $\begin{array}{l}\text { permohonan } \\
\text { pengambila } \\
\mathrm{n} \text { salinan } \\
\text { putusan }\end{array}$ & \\
\hline 18 & $\begin{array}{l}\text { Membuat } \\
\text { permohonan } \\
\text { pengambila } \\
\mathrm{n} \text { salinan } \\
\text { putusan }\end{array}$ & $\begin{array}{l}\text { Memasukka } \\
\mathrm{n} \quad \text { data } \\
\text { kedalam } \\
\text { form yang } \\
\text { disediakan }\end{array}$ & $\begin{array}{l}\text { Data dikirim } \\
\text { ke halaman } \\
\text { daftar } \\
\text { perkara pada } \\
\text { halaman } \\
\text { admin }\end{array}$ & $\begin{array}{l}\text { Tercapa } \\
\text { i }\end{array}$ \\
\hline
\end{tabular}

\section{KESIMPULAN}

Berdasarkan penelitian yang sudah dilakukan, kamitelah membuat sistem berbasis web dengan nama Sistem Informasi Aplikasi Penelusuran Putusan (SIAPP). Dalam pengembangan sistem ini kami menggunakan metode Rapid Application Development (RAD). Website ini akan membantu mempermudah masyarakat pencari keadilan dalam mengambil salinan putusan dan juga mempermudah Pengadilan Negeri Tondano dalam menyiapkan salinan putusan.

\section{UCAPAN TERIMA KASIH}

Kami mengungkapkan penghargaan yang tulus kepada Bapak/Ibu Dosen Pembimbing Kerja Praktek, yang sangat membantu para penulis lewat saran dan masukan dalam menyelesaikan artikel. Penulis bersama berterima kasih kepada pihak Pengadilan Negeri Tondano atas segala sumbangsi sehingga aplikasi yang penulis kembangkan bisa diselesaikan.

\section{DAFTAR PUSTAKA}

[1] Shalahuddin, Rosa A. S. M, Rekayasa Perangkat Lunak Terstruktur dan Berorientasi Objek, Bandung, April 2018.

[2] http://agungsr.staff.gunadarma.ac.id/Downloads/files/3412/Konsep + SI.\%20pdf, 17 Maret 2020

[3] http://library.binus.ac.id/eColls/eThesisdoc/Bab2/2012-2-00081MNSI\%20Bab2001.pdf, 17 Maret 2020.

[4] https://ejurnal.teknokrat.ac.id/index.php/teknoinfo/article/downloa d/24/24, 17 Maret 2020 .

[5] https://library.binus.ac.id/eColls/eThesisdoc/Bab2/2011-2-01644IF\%20Bab2001.pdf, 18 Maret 2020.

[6] http://jurnalmahasiswa.unesa.ac.id/index.php/jurnal-manajemen-

[7] informatika/article/download/17937/16345, 18 Maret 2020.

[8] https://ejournal.itp.ac.id/index.php/tinformatika/article/download/ 546/454, 18 Maret 2020.

[9] https://piyaneo.wordpress.com/2014/05/10/rapid-applicationdevelopment-rad/ 13 Mei 2020. 